\title{
An unexpected case of ventricular fibrillation cardiac arrest in a Caucasian female
}

\author{
Louisa O'Neill, ${ }^{1}$ Rory O'Hanlon, ${ }^{2}$ Patrick Owens, ${ }^{1}$ Andrew Maree ${ }^{1}$
}

${ }^{1}$ Department of Cardiology, Waterford Regional Hospital, Waterford, Ireland

${ }^{2}$ Department of Cardiology, Blackrock Clinic, Dublin, Ireland

\section{Correspondence to} Dr Louisa O'Neill,

louisaoneill@yahoo.co.uk

Accepted 15 October 2014

\section{DESCRIPTION}

A 53-year-old Caucasian woman suffered an out-of-hospital cardiac arrest and was successfully resuscitated. She had no cardiac history and there was no family history of sudden cardiac death.

A 12-lead ECG showed deep Twave inversion in the anterolateral leads (figure 1A). Two-dimensional echocardiography in the apical four-chamber view demonstrated asymmetric hypertrophy of right and left ventricular apices (figure 1B). Systolic anterior motion of the mitral valve was not present. Cardiac MRI in four-chamber cine view clearly demonstrates asymmetric hypertrophy of right and left ventricular apices with an 'ace of spades' appearance to the left ventricular apex (figure 1C, white arrows; video). Prominent mid wall fibrosis is noted on late gadolinium imaging in the maximally hypertrophied apices (figure 1D, white asterisk). Coronary angiography confirmed patent coronary arteries. An implantable cardioverter-defibrillator was inserted and family screening initiated.
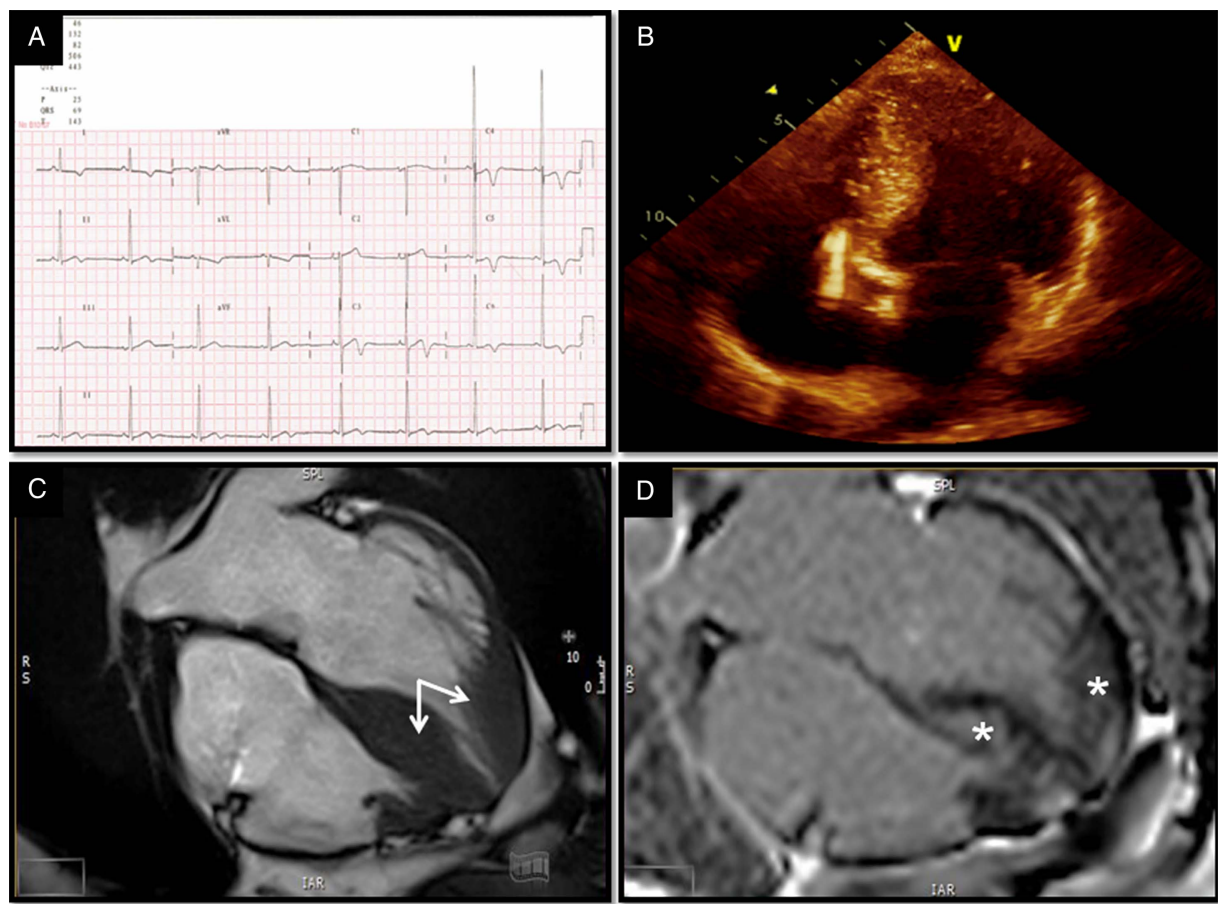

Figure 1 (A) ECG showing deep T wave inversion in anterior leads. (B) Two-dimensional four-chamber echo view showing asymmetric hypertrophy of the right and left ventricular apices. (C) Cardiac MRI four-chamber cine view showing asymmetric apical hypertrophy with 'ace of spades' appearance to the left ventricular apex. (D) Cardiac MRI four-chamber view showing mid-wall fibrosis in maximally hypertrophied regions.

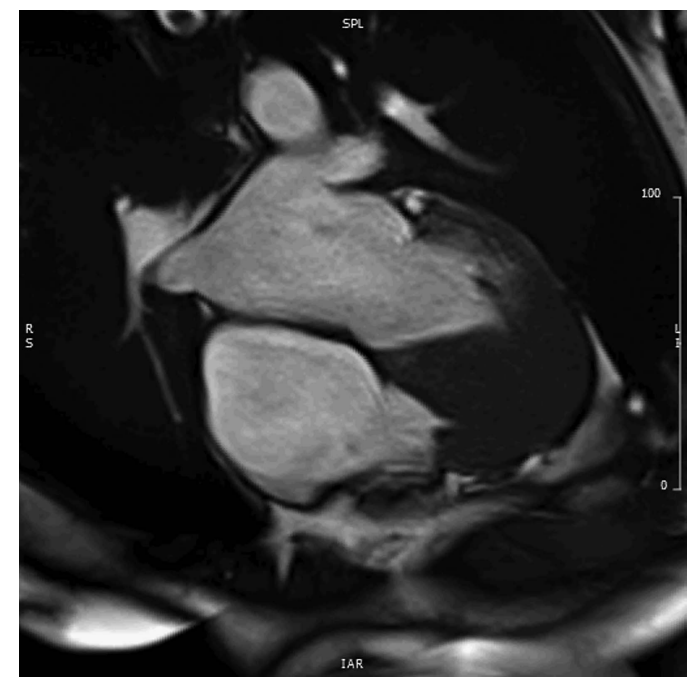

Video 1 Cardiac MRI four chamber view demonstrating asymmetric apical hypertrophy with ace of spades appearance to left ventricle.
To cite: $O^{\prime} N$ ill $L$,

O'Hanlon R, Owens $\mathrm{P}$, et al. BMJ Case Rep Published

online: [please include Day Month Year] doi:10.1136/ bcr-2014-206762 


\section{Learning points}

- Although apical hypertrophic cardiomyopathy (HCM) is considered a more benign variant of HCM with low risk for sudden cardiac death, this case highlights that malignant ventricular arrhythmias may occur in this phenotype and emphasises the importance of continuous risk assessment. ${ }^{1}$

- Further study is required to improve risk stratification of the apical HCM variant. ${ }^{2}$

- Non-invasive assessment of ischaemia, fibrosis and apical aneurysms using cardiac MRI may assist in this process. $^{3}$
Competing interests None.

Patient consent Obtained.

Provenance and peer review Not commissioned; externally peer reviewed.

\section{REFERENCES}

1 Eriksson MJ, Sonnenberg B, Woo A, et al. Long-term outcome in patients with apical hypertrophic cardiomyopathy. J Am Coll Cardiol 2002;39:638-45.

2 Maron MS, Finley JJ, Bos JM, et al. Prevalence, clinical significance, and natural history of left ventricular apical aneurysms in hypertrophic cardiomyopathy. Circulation 2008;118:1541-9.

3 O'Hanlon R, Grasso A, Roughton M, et al. Prognostic significance of myocardial fibrosis in hypertrophic cardiomyopathy. J Am Coll Cardiol 2010;56:867-74.

Copyright 2014 BMJ Publishing Group. All rights reserved. For permission to reuse any of this content visit http://group.bmj.com/group/rights-licensing/permissions.

BMJ Case Report Fellows may re-use this article for personal use and teaching without any further permission.

Become a Fellow of BMJ Case Reports today and you can:

- Submit as many cases as you like

- Enjoy fast sympathetic peer review and rapid publication of accepted articles

- Access all the published articles

- Re-use any of the published material for personal use and teaching without further permission

For information on Institutional Fellowships contact consortiasales@bmjgroup.com

Visit casereports.bmj.com for more articles like this and to become a Fellow 